\section{Fatores Hormonais e Genéticos na Próstata Normal e Neoplásica}

revisão

\section{RESUMO}

Recentemente, tem sido dada muita atenção para os efeitos proliferativos dos andrógenos nas células prostáticas. Isso tem despertado grande interesse no papel desses hormônios esteróides no desenvolvimento e manutenção tanto da próstata normal quanto maligna. Entretanto, até o presente, não tem sido identificada a relação exata entre os niveis hormonais e o risco de neoplasia. O complexo andrógenoreceptor, após associação com elementos no DNA que respondem ao hormônio, promove especificamente o crescimento da glândula Já foi reconhecido que existe uma estreita ligação entre o seu padrão de sinalização citoplasmática e aquele desencadeado pelos fatores de crescimento. Muito progresso tem sido obtido a partir do estudo dessas interações o que pode levar ao desenvolvimento de novas e eficientes abordagens terapêuticas no câncer de próstata. (Arq Bras Endocrinol Metab 1999;43/3: 177-185)

Unitermos: Próstata; Neoplasia prostática; Andrógenos; Fatores de crescimento: Terapia.

\begin{abstract}
Recently, a great deal of attention has focused on the growth regulato. ry effects of androgens in prostate cells. This has also resulted in much interest in the role of these steroid hormones in the development and maintenance of both normal and neoplastic prostate. However, it has not been possible to identify the exact relationship between androgenic hormone levels and the risk of this disease. The hormone-androgen receptor complex, by association with the DNA androgen response elements, specifically promotes the growth of the prostate gland. It has been recognized that there is a close relationship between the androgen mediated signaling pathway and those promoted by peptide growth factors. More insights are being gained into these complex interactions, some of which may lead to novel therapeutic maneuvers. (Arq Bras Endocrinol Metab 1999:43/3: 177-185).
\end{abstract}

Keywords: Prostate; Prostatic neoplasia; Androgens; Growth factors; Therapy.

\section{CONSIDERAÇŌES GERAIS}

A Próstata É um órciăo firme, de consistência fibroclástica, que pesa
localizada na base da bexiga urinária e, do ponto de vista anatômico, pode
ser dividida em lobos laterais, anterior, posterior e mediano. Essa divisão
somente é nítida no período embrionário e, no orgão adulto, o limite entre
os lobos é impreciso, não existindo septos de tecido conjuntivo que os se-
parem. Histologicamente, apresenta dois tipos glandulares, tubuloacinosas
compostas e ramificadas, cuja secreção tem como principal função manter
Andréa B. Carvalho-Salles
Eloiza Helena Tajara Departamento de Biologia, Instituto
de Biociências, Letras e Ciéncias
Exatas, Universidade Júlio de
Mesquita Fillono (IBILCE/UNESP),
São José do Rio Preto, SP. 
a viabilidade dos espermatozóides. As glândulas externas ou prostáticas propriamente ditas definem a zona periférica, e as internas ou periurctrais definem a zona central $(1,2)$.

As glândulas da zona periférica caracterizam-se por pequenos espaços acinares delimitados por um epitélio colunar secretor, rodeado por um estroma muscular rico em fibras lisas que, durante a ejaculação, aurxiliam o esvaziamento das secreções prostáticas na uretra. A zona central, por sua vez, contém ácinos relativamente grandes delimitados por um epitélio colunar baixo. A disposição com que os ductos dessa região desembocam na uretra parece torná-los relativamente livres do refluxo urinário intraprostático, ao contrário daqueles da região periférica. Uma terceira zona pode ainda ser identificada, a de transiçăo, que compreende $5 \%$ a $10 \%$ da glândula e cujos ductos desembocam na uretra, próximos aos da zona central (3).

A próstata cstá presente cstruturalınente desde a décima segunda semana de vida intra-uterina e permanece rudimentar até a adolescência, quando inicia. seu desenvolvimento (3). A partir dessa época, seu crescimento é contínuo e dependente de um sistema regulatório complexo, com participação dos andrógenos durante os processos de morfogênese, citodiferenciação, proliferação e produção de secreções específicas. Esses hormônios, produzidos principalmente nos testículos, exercem seu efeito biológico na próstata atravessando a membrana plasmática das células por difusão e ligando-se a receptores intracelulares. Essa união é responsável pela dimerização e transporte do complexo hormônio-receptor e pela induçăo da transcrição de genes alvo. Os produtos resultantes da transcrição incluem fatores de crescimento, além de seus receptores c outras proténas tecido-específicas relacionadas com o desenvolvimento e diferenciação da glândula $(4,5)$.

\section{REGULAÇÃO HORMONAL DA PRÓSTATA}

Os andrógenos desempenham um importante papel durante a diferenciação e o desenvolvimento da próstata normal mas são também responsáveis pela iniciação c pela manutençăo da lijperplasia benigna e do câncer prostático (6). Desses andrógenos, 95\% correspondem à testosterona (TT) produzida nas células de Leydig dos testículos, por estimulaçăo do hormônio luteinizante (LH) da hipófise que, por sua vez, é regulado pelo hormônio liberador de gonadotrofinas (GnRH) do hipotálamo (Figura 1). Os outros 5\% de andrógenos são sintetizados nas adrenais sob a ação do hormônio adrenocorticotrófico (ACTH) da hipófise,

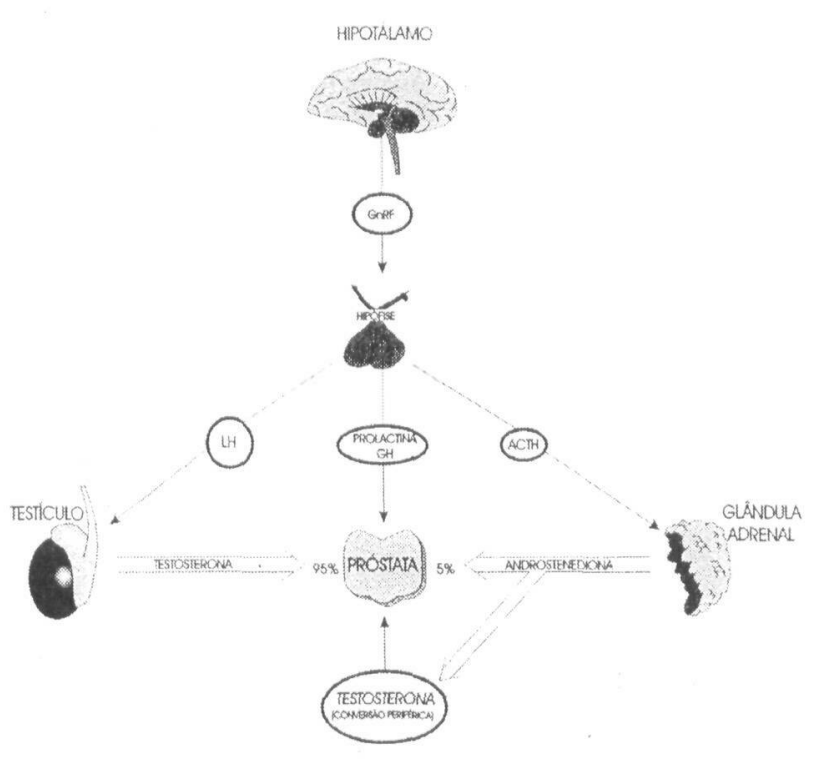

Figura 1. Hormônios envolvidos na regulação endócrina da glândula prostática. GnRH: Hormônio Liberador de Gonadotrofinas; LH: Hormonio Luteinizante; ACTH: Hormônio Adrenocorticotrófico.

que é regulado pelo GnRH, e libcrados principalmente na forma de androstenediona, que é perifericamente convertida $\mathrm{cm}$ testosterona (4). A prolactina e o hormônio de crescimento (GH) também cstimulam a produção de andrógenos tanto nos testículos como nas adrenais, tendo a primcira um efeito mitogênico dircto adicional sobre as células epiteliais da próstata (7).

A principal enzima da biossíntese da TT é a $17 \alpha$-hidroxilase $/ \mathrm{C}_{17}, 20$ liase, que converte, por hidroxilação e clivagem da cadeia lateral, a pregnenolona e a progesterona em deidrocpiandrosterona $\mathrm{c}$ androstenediona, depois transformadas em andros tenediol e testosterona, respectivamente, pela ação da $17 \beta$-hidroxicsteróide desidrogenase (17 $\beta$-OHSD). O androstenediol, pela ação da $3 \beta$-hidroxiesteróide desidrogenase ( $3 \beta-O H S D)$, também é convertido $\mathrm{cm}$ testosterona que é liberada na cireulação sangúnea c ligi-se a albumina (Figura 2). Somente 5\% desse esteróide permanece livre no plasma e biologicamente ativo $(5,7-9)$.

O mecanismo de ação dos andrógenos sobre a próstata constitui uma secjüencia integrada de eventos. Inicialmente, a TT atravessa a membrana plasmática das células por interação hidrofóbica com os fosfolipídios e é metabolizada no núcleo em diidrotestosterona (DHT) através de uma reação catalisada pela enzima 
COLESTEROL

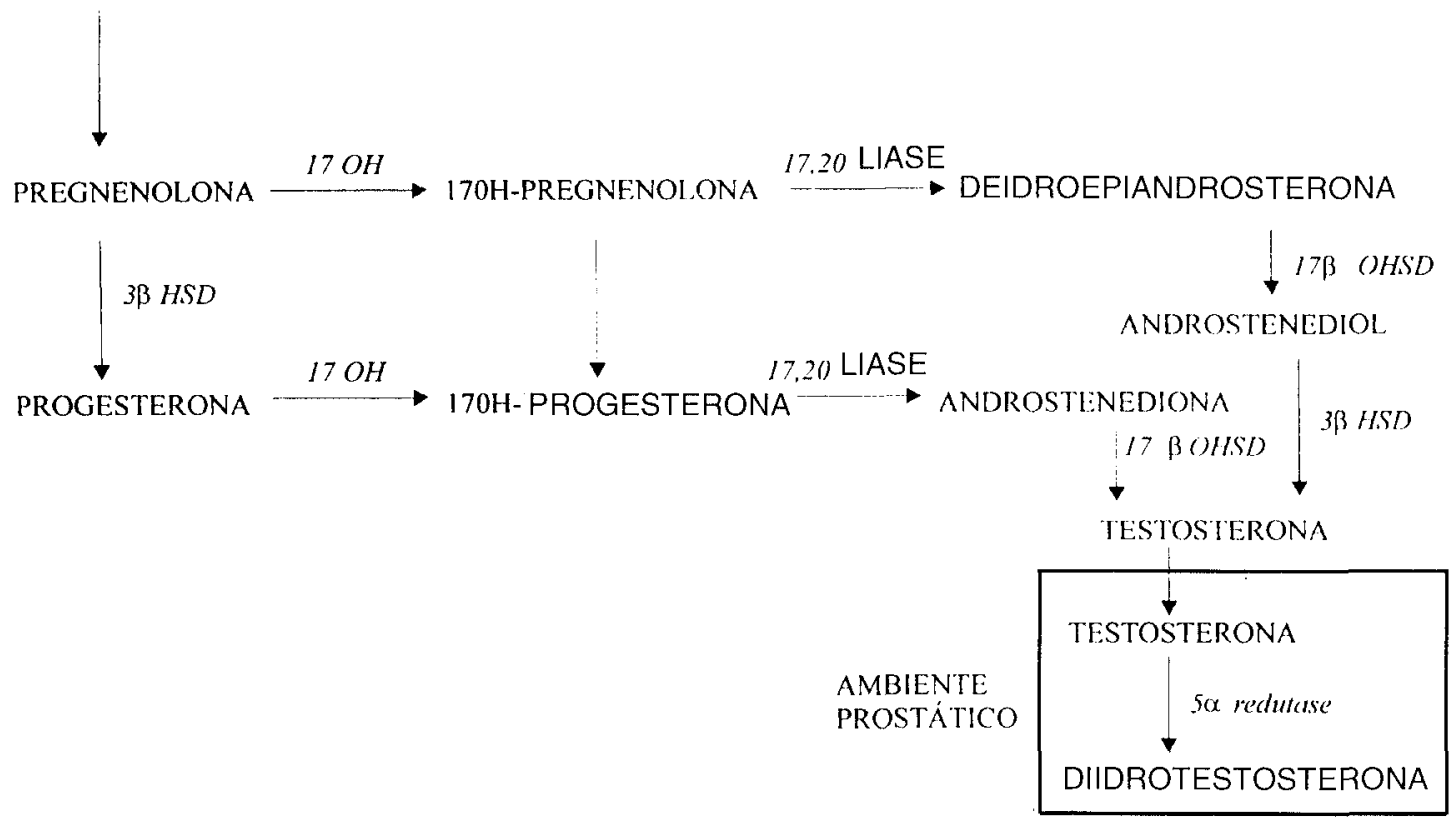

Figura 2. Esquema da biossintese dos andrógenos. Pregnenolona e progesterona são convertidas em testosterona que é liberada na corrente sangüínea, atravessa a membrana plasmática das células epiteliais prostáticas e é metabolizada em diidrotestosterona.

$5 \alpha$-redutase presente no envoltório nuclear (4). A DHT, um andrógeno mais potente que a TT co principal hormônio trófico da próstata, liga-se com grande afinidade a receptores androgênicos (AR), uma proteína nuclear que é expressa na maioria das células prostáticas, incluindo as epiteliais e as do estroma $(5,10)$. Embora a TT também possua a capacidade de ligar-se a tais receptores, seu papel parece ser secundário ao da DHT, uma vez que não ocorre o desenvolvimento da glândula $\mathrm{em}$ homens portadores de deficiência da enzima $5 \alpha$-redutase (11).

O complexo DHT-receptor modula a expressão de vários genes através de sua ligação com seqüências consenso no genoma chamadas elementos que respondem ao hormônios (HREs). Essas estruturas são formadas por centenas de pares de base e, geralmente, estão situadas nas regiǒes promotoras ou de enhancers (6). O AR, após sua ligação à DHT, exibe seus dois zinc fingers, que facilitam sua associação aos HREs (Figura 3). Aparentemente, essa mudança conformacional ocorre porque o receptor libera a proteína 90 do choque térmico, à qual está ligado quando na sua forma inativa. Isso permite a sua dimerização $\mathrm{c}$ a conseqücnte estabilidade necessária para o processo de transcrição gênica $(6,7)$.

Os genes sob controle do DHT-AR codificam várias protcínas, inclusive alguns fatores de crescimen-

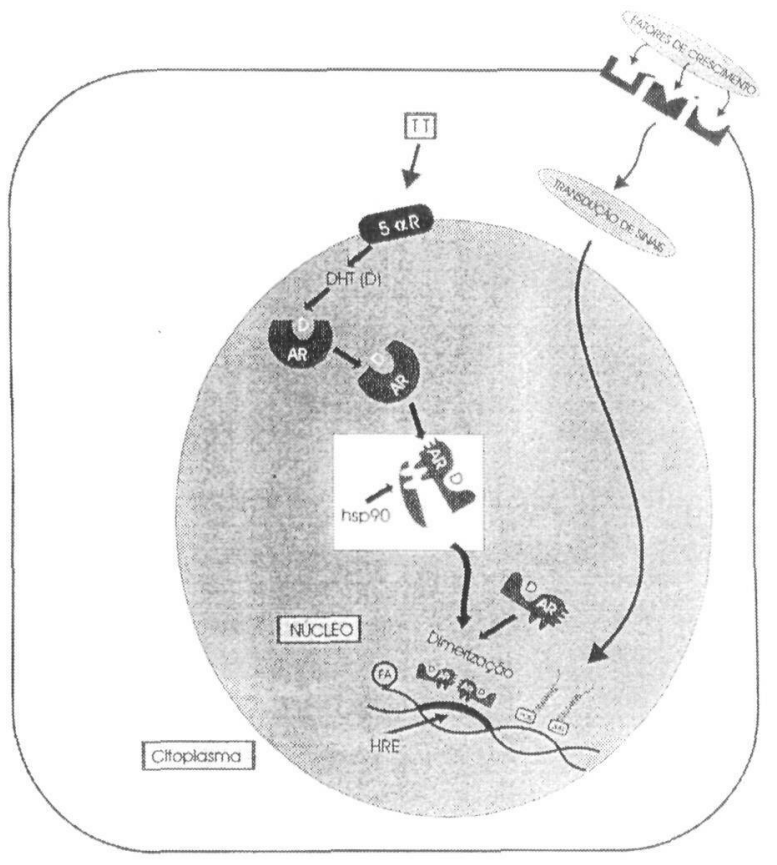

Figura 3. Ilustração mostrando os processos intracelulares de célula epitelial prostática que ocorrem após a formação do complexo DHT-AR, sua conseqüente alteração conformacional após a liberação da proteína hsp 90 e interação funcional com o fator AP-1 na transcrição gêni-

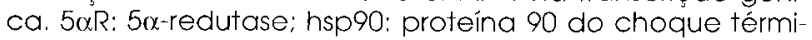
co; FA: fator acessório (modificada de Griffiths et al., 1997). 
to importantes, que foram identificados como estimuladores potenciais da proliferação celular prostática $(6,12)$. Entre eles estão os fatores de crescimento epidérmico e de fibroblastos (EGF e FGF), o semelhante à insulina (IGF-I c II), o transformante $\beta$ (TGF $\beta$ ), o derivado de plaqueta (PDGF) e o de queratinócitos (KGF). Os sinais mitogênicos intrácrinos, autócrinos e parácrinos (Figura 4) são iniciados pela ligação desses fatores aos domínios externos dos seus receptores presentes na membrana celular, o que estimula a atividade de tirosina quinase situada no domínio intracelular do receptor e inicia uma cascata de sinais até o núcleo. Esses sinais regulam a transcrição de genes específicos, tais como do antígeno específico da próstata (PSA), ou de protoncogenes, como o C-MYC, C-FOS ou C-JUN, que codificam proteínas envolvidas no processo normal de proliferação celular $(6,13)$. Os produtos gênicos de C-FOS e C-JUN, por exemplo, formam homo ou heterodímeros através de seus domínios leucine zippers $\mathrm{e}$ são componentes do fator de transcrição AP-l (14). O

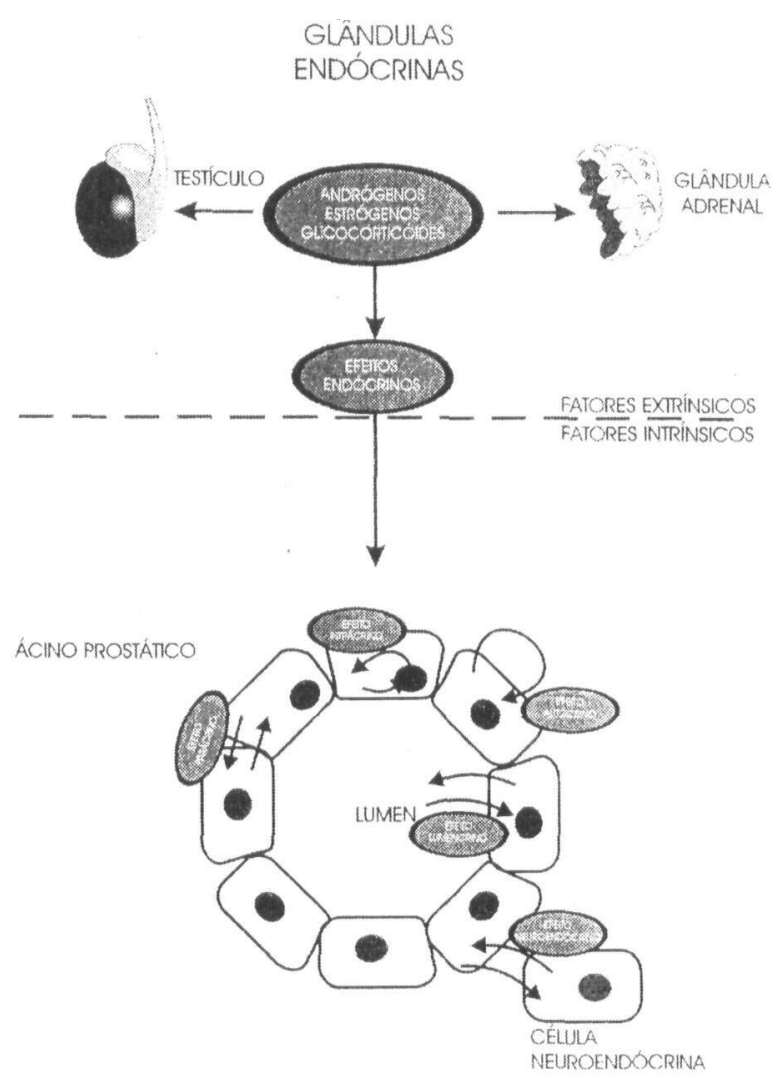

Figura 4. Fatores extrínsicos envolvidos na proliferação da célula prostática (modificada de Griffiths et al. 1997). complexo AP-1 reconhece seqüências específicas no genoma, que se encontram próximas ao elementos HREs nas regiōes promotoras de genes que respondem ao hormônio (15). Essa proximidade de seqüiências reguladoras indica uma interação funcional (Figura 3) do complexo DHT-AR e do AP-1, aparentemente necessária para a transcrição de genes alvo (6).

Além das cascatas de sinais desencadeados pelos andrógenos e pelos fatores de crescimento, outras substâncias também participam dos processos de desenvolvimento e diferenciação da próstata. Por exemplo, as células neuroendócrinas, presentes na glândula, contêm grânulos secretores com substâncias da família das cromograninas e das proteínas semelhantes ao hormônio da paratireóide, além de serotonina, somatostatina, bombesina e calcitonina que possuem atividades semelhantes às dos fatores de crescimento. Essas substâncias são importantes na proliferação das células prostáticas e atuam através de vários mecanismos de regulação, incluindo o autócrino e o parácrino (Figura 4).

O envolvimento desses compostos no crescimento e na diferenciação prostática constituem uma prova de que esses processos são complexos c não têtn os andrógenos como fatores atuantes exclusivos $(7,16,17)$.

\section{O RECEPTOR DE ANDRÓGENOS}

O AR é um fator transcricional, membro da superfamília de proteínas regulatórias nucleares que inclui, além de outros receptores de esteróides, o receptor do hormônio da tiróide e do ácido retinóico $(18,19)$. Essas proteínas são relacionadas entre si por causa da alta homologia do seu domínio responsável pela ligação com as seqüências HREs do genoma $(18,20)$.

$O$ receptor de andrógenos é uma proteína formada por 910 aminoácidos e, estruturalmente, organizada em três domínios funcionais: o amino-terminal, que é essencial para a ativação da transcrição; a seqüência central, rica em cisteína e com dois zinc fingers, que é altamente conservada e responsável pela ligação do receptor com os elementos HREs do DNA; e o domínio carboxi-terminal, que se liga ao andrógeno (21 23). O gene está localizado na banda $\mathrm{X}_{\mathrm{q}} \mathrm{l} \mathrm{l}-12$ (24) e sua região codificadora está dividida em oito exons. A seqüência que codifica o domínio amino-terminal da proteína está presente no exon 1 , enquanto o domínio de interação com o DNA é codificado pelos exons $2 \mathrm{e}$ 3 e a informação para o domínio de ligação com o esteróide está distribuída entre os exons 4 a $8(21,23)$. A deficiência completa ou parcial do domínio amino- 
terminal ou da região de ligaçăo com o DNA inativa a capacidade transcricional do AR, mesmo quando o receptor encontra-se associado ao andrógeno. Por outro lado, a maioria das alterações observadas na região carboxi-terminal impede sua ligaçăo com o esteróide, porém, ativa a funç̧̃o transcricional mesmo na ausência do hormônio (25-27).

As comparaçóes intra e interespecíficas mostram que as sequiências de aminoácidos dos domínios de ligação com o DNA e da regiăo de ligação com o hor mônio são conservadas, tanto para o mesmo receptor como para receptores diferentes da mesma superfamília $(21,28)$. Essa conservação evolutiva levou alguns pesquisadores a questionarem a especificidade transcricional in vivo, uma vez que os diferentes receptores de esteróides reconhecem uma mesma sequiência de DNA (29). Uma das explicações dada foi que a regulação transcricional envolve a participação de fatores accssórios (Figura 3) que atuan como ativadores ou repressores transcricionais (30). Por exemplo, a ERAP160 e a GRIPI funcionam como coativadores dos complexos receptor de estrógeno-DNA e receptor de glicocorticóide-DNA, respectivamente $(31,32)$, a SRC-1 estimula a função de transativação de todos os receptores de esteróides (33) e a $\mathrm{ARA}_{70}$ desempenha a função de coativador específico da atividade transericional do AR nas células prostáticas humanas (34). Como exem. plos de repressores estão os fatores de transcrição $\mathrm{N}$ CoR e SMRT, que atuam sobre os receptores do hormônio da tiróide e do ácido retinóico (35-37).

No domínio amino-terminal do AR, existem duas sequiências polimórficas de trinucleotídeos CAG e GGC (38). As expansões CAG, que nomalmente atingem de 11 a 33 repetições (com média de 20 ), codificam uma cadeia de poliglutamina na posiçăo 172 e as repetições GGC codificam poliglicinas na posição 1342 da proténa. Tais expansões parecem estar inversamente relacionadas com sua atividade transcricional nas células prostáticas $(28,39,40)$.

O estudo de Irvine et al. (4l) em três grupos raciais diferentes mostrou uma predominância de alelos CAG pequenos nos negros americanos, que possuem um risco aumentado de desenvolver essa doença, tamanhos intermediários em homens brancos de origem não hispânica e número baixo de repetições $\mathrm{em}$ asiáticos, que manifestam as freqüências mais baixas desse tipo de neoplasia. Giovannuci et al. (42), avaliando o número de repetições CAG no gene do AR de amostras de adenocarcinomas prostáticos, concluíram que tumores com fenótipos mais agressivos, quando comparados aos menos agressivos, possuíam seqüîncias polimórficas mais curtas.
Extensões homopoliméricas de aminoácidos semcihantes a essas têm sido observadas em muitas proteínas (43). Por exemplo, seqüências com 20 ou mais resíduos de poliglutamina já foram referidas em muitos fatores de transcrição, incluindo a proteína NOTCH em drosófila (44), o fator de transcrição IID na espécic humana $(45,46)$, a GAL4 em leveduras (43) e o AR de diferentes organismos (20). Repetiçōes de trinucleotídeos são descritas também em genes de algumas doenças hereditárias. É o caso dos alelos do próprio gene do AR, que exibe de 40 a 62 repetições CAG no amino-terminal e causam a doença de Kennedy, uma síndrome neuromuscular degenerativa com insensibilidade ao andrógeno. Também são conhecidos os alelos dos genes responsáveis pela doença de Huntington, pela ataxia espinocerebelar tipo 1 , pela doença de Machado-Joseph e pela síndrome do X frágil, que manifestam desde algumas dezenas até milhares de trinucleotideos CAG on CGG (47). Certos alelos do gene SRD5A2, responsável pela síntese isoenzima tipo II da 5 a redutase expressa na próstata, também contêm repetições de dinucleotídeos (TA) $)_{11}$ na região 3 ' o que parece elevar a atividade da enzima, o nível de DHT na próstata e, consequentemente, os riscos de desenvolver alguns tipos de câncer prostático $(48,49)$.

\section{MECANISMOS MOLECULARES DA INDEPENDÊNCIA HORMONAL DAS CÉLULAS NEOPLÁSICAS DA PRÓSTATA}

O câncer de próstata é a segunda causa de morte relacionada a neoplasia entre os homens em alguns países. É uma doença heterogênea, caractcrizada por variaçoes nas taxas de proliferaçăo, resposta a terapias e idade de início, cujos fatores etiológicos incluem predisposição genćtica familial. Na época em que é feito o diagnóstico, aproximadamente $50 \%$ dos casos estão confinados à glândula e a outra metade possui metás. tases distantes envolvendo preferencialmente o tecido osseo. Entre os tumores localizados, alguns permanecem indolentes por muitos anos, enquanto outros adquirem um comportamento agressivo e geralmente levam scu portador à morte (3). Os carcinomas $\mathrm{cm}$ estágios avançados são, geralmente, tratados com terapias que diminuem a atividade dos andrógenos circulantes, como a castração cirúrgica, a administração de análogos do hormônio luteinizante ou a inibição da atividade normal do AR por substâncias antiandrogênicas (50).

Os antiandrógenos são freqüentemente utilizados para o tratamento das lesões hormôniodependentes e sua ação é baseada no potencial de 
competição pelos sítios do AR, sem a sua correspondente ativação. Com relação aos efeitos fisiológicos, podem ser divididos em dois grupos: os esteróides e os não csteróides. O primeiro grupo bloqueia a ação do andrógeno e possui atividade de glicocorticóide c de progesterona, cssa última capaz de reprimir a produção do hormônio luteinizante e, consequentemente, da TT c da DHT. O segundo grupo, embora com capacidade de bloqueio de andrógenos, cstimula o cixo hipotálamo - hipófise - gônada, o que pode levar a um aumento no nível desses hormônios (23). Em ambos os casos, os mecanismos de ação incluem a indução de uma conformação anormal do receptor (51), a deficiência no transporte do complexo hormônio-AR $(52,53)$, a falha na dissociação do complexo heterodimérico do receptor (53), e a sua dimerização ou ligação incompletas com o DNA (54).

Cerca de $20 \%$ dos tumores não possuem qualquer resposta à manipulação endócrina e muitos casos năo mostram remissão permanente podendo, em um tempo variável, tornar-se hormônio-indcpendentes e não responderem mais ao tratamento $(55,56)$. Existem alguns fatores que contribuem para a incficiência desse tipo de terapia. Por exemplo, os níveis hormonais na corrente sangǘnca podem não refletir o padrão androgênico intracelular da glândula c, assim, a manipulação do hormônio circulante ter apenas um pequeno impacto na proliferação do tecido prostático (56).

Outros fatores responsáveis pela falha na resposta ao tratamento são aqueles rclacionados com a ativação permanente do receptor hormonal, mesmo na presença de concentraçóes baixas de andrógenos. Hobisch et al. (57), através da técnica de imunohistoquímica, observaram a presença do $\mathrm{AR}$ em todas as amostras de metástases de carcinomas prostáticos humanos que haviam adquirido independência androgênica durante a terapia. Os autores concluiram quc, provavelmente, a alteração do receptor está envolvida na progressão do tumor, o que poderia levar ao estímulo do crescimento mesmo na ausência do hormônio ou então, à inespecificidade do receptor cm relação ao esteróide. Realmente, a análise do gene AR tem demonstrado que mutaçõcs específicas, como deficiências nos exons 4 a 8 , conferem vantagem proliferativa em alguns tipos de câncer hormônio-inde pendentes (58) mas parece ser um evento incomum nos tumores $\mathrm{cm}$ estágios iniciais (59).

Gaddipati et al. (58), utilizando amostras de pacientes com câncer de próstata metastático, detectaram uma substituição freqüente no códon 877
$(\mathrm{ACT} \rightarrow \mathrm{GCT}, \mathrm{Thr} \rightarrow \mathrm{Ala})$, presentc no cxon quc codifica o domínio de ligação $\mathrm{com}$ o hormônio. Mutaçôes nessa região também foram descritas em uma linhagem celular muito bem caracterizada, a LNCaP $(60,61)$, que é derivada de um nódulo linfático de paciente portador de tumor prostático disseminado, inicialmente tratado com administração de estrógeno e castração cirúrgica. É interessante citar que, na presença dessa mutação, os antiandrógenos têm um efeito estimulador sobre a proliferação. Assim, é possivel que essa alteração dificulte a resposta aos agentes terapêuticos usados.

O estudo de Koivisto et al. (62) mostra uma relação entre amplificações do gene do AR e resistência à terapia hormonal. Os autorcs observaram que tais amplificações ocorrem exclusivamente em tumores recorrentes que foram tratados com terapia de depleção hormonal durante um periodo maior que 12 meses. As lesões que não apresentaram, inicialmente, resposta ao tratamento androgênico ou aquelas que recorreram em um período inferior a um ano não possuíam amplificações do gene. Portanto, essa mutação não está correlacionada com a gênese do câncer ou mesmo com a progressão clínica de tumores não tratados. O aumento no número de cópias do gene c, conscquentemente do seu produto, parece potencializar a resposta da célula, mesmo em baixas concentrações de andrógenos e deve scr responsável pela resistência à terapia hormonal adquirida. Por outro lado, a falha no tratamento de tumores inicialmente independentes ao hormônio, parece ser causada por outros mecanismos não relacionados com a amplificação do gene do AR.

Vários experimentos têm sugerido que a transformação de uma célula tumoral hormônio-dependente para um estágio de independêneia hormonal pode não envolver alterações no gene do receptor. A ativação de protoncogenes ou a inativação de genes supressores de tumor seriam as responsáveis pela proliferação celular mesmo na ausência de csteróides (7). Realmente, a introdução do oncogenc $R A S$ ativado em células da linhagem LNCaP é suficiente para fazcr a sua conversão para a condição andrógeno-independente (63). Outras linhagens celulares hormônio-independentes possuem mutações no gene supressor de tumor RBI (64) e tumores em estágios avançados mostram alterações no gene TP53, que está envolvido no controle do ciclo celular e na apoptose (65). Esses achados mostram que a situação é complexa e ilustra bem que a tumorigênese na próstata deve compreender múltiplos eventos responsáveis por vantagens proliferativas em ambientes internos diferentes. 


\section{CONCLUSÕES}

O esclarecimento do papcl, da fisiologia e dos cventos biológicos responsáveis pela produção de andrógenos c de seu receptor é essencial para o entendimento dos mecanismos envolvidos no desenvolvimento das células normais c neoplásicas da próstata e na progressão tumoral dessa glândula. Entre csses mecanismos, estão os sinais descncadcados pelos fatores de crescimento $\mathrm{c}$ pelo receptor de andrógenos, as alterações que aumentam ou tomam a atividade desse receptor independente do estímulo hormonal e as variaçōes no número de repetições das seqüências de trinuclcotídcos CAG e GGC no seu gene, que estão inversamente relacionadas com sua atividade transcricional nas células prostáticas. Embora progressos recentes tenham sido feitos no entendimento da tumorigênese prostática, muitos estudos são ainda necessários para a identificação de todos os fatores que participam do processo e para o desenvolvimento de novas e eficientes abordagens terapêuticas dessa doença.

\section{REFERÊNCIAS}

1. Rodrigues Neto Jr N. Urologia. São Paulo: Livraria Roca, 1986.

2. Cotran RS, Kumar V, Robbins SL, Patologia Estrutural e Funcional. $4^{a}$. ed. Rio de Janeiro: Koogan, 1991

3. Kirby SR, Christimas TJ, Brawer M. Prostate Cancer. Mirror, 1996.

4. Meikle AW. Endocrinology of the prostate and of benign prostate hyperplasia. In DeGroot LJ, ed. Endocrinology Philadelphia: Sauders, 1985: 2459-73.

5. SBU. (1996). Treatment in Mass screening for Prostate Cancer, p. 46-61

6. Griffiths K, Morton MS, Nicholson RI. Androgens, androgens receptors, antiandrogens and treatment of prostate cancer. Eur Urol 1997;32:24-40.

7. Galbraith SM, Duchense GM. Androgens and prostate cancers: biology, pathology and hormonal therapy. Eur $\mathrm{J}$ Cancer 1997;33:545-54.

8. Chung B, Picado-Leonard J, Hanju M, Bienkowski M, Hall PF. Cytochrome P 450ci7 (steroid 17a-hydroxylase/17,20 lyase): cloning of human adrenal and testis CDNA indicates the same gene is expressed in both tissues. Proc Natl Acad Sci USA 1987:84:407-11

9. Klus GT, Nakamura J, Li J, Ling Y. Son C, Kemppainen J, et al. Growth inhibition of human prostate cells in vitro by novel inhibitors of androgen sythesis. Cancer Res 1996:56:4956-64.

10. Iwamura M, Abrahamsson PA, Benning CM, Cockett AT, Di Sant'Agnese PA. Androgen receptor immunostaining and its tissue distribution in formalin-fixed, paraffinembedded sections after microwave treatment. J Histochem Cytochem 1994:42:783-8.
11. Imperato-McGinley J, Gautier T, Zirinsky K, Hom T, Palomo O. Stein E, et al. Prostate visualization studies in males homozygous and heterozygous for 5 alpha-reductase deficiency. J Clin Endocrinol Metab 1992;75: 1022-6.

12. Brass AL, Bernard J, Patai BL, Salvi D, Rukstails S. Androgen up-regulates epidermal growth factor receptor expression and binding affinity in PC3 cell lines expressing the human androgen receptor. Cancer Res $1995 ; 55: 3197-203$.

13. Aaronson SA. Growth factors and cancer, Science 1991:254:1146-3

14. Lewin B. Genes VI. New York: Oxford University Press, 1997.

15. Jones N. Transcriptional regulation by dimerization: two sides to an incestuous relationship. Cell 1990;61:9-11.

16. Kooistra A, Konig JJ, Romijn JC, Schroder FH. Negative control of epithelial cell proliferation by prostatic stroma. Anticancer Res 1991;11:1495-500.

17. Sant'Agnese A, Cockett ATK. Neuroendocrine differentiation in prostatic malignancy. Cancer 1996:78:357-61.

18. Evans RM. The steroid and thyroid hormone receptor superfamily. Science 1988:240:889-95.

19. Lubahn DB, Joseph DR, Sullivan PM. Willard HF, French FS, Wilson EM. Cloning of human androgen receptor complementary DNA and localization to the $X$ chromosome. Science 1988;240:327-30.

20. Chang C, Kokontis J, Liao S. Molecular cloning of human and rat complementary DNA encoding androgen receptors. Science 1988:240:324-6.

21. Chang, C, Kokontis J, Liao S. Structural analysis of complementary DNA and amino acid sequence of human and rat androgen receptors. Proc Natl Acad Sci USA 1988;85:7211-5.

22. Brinkmann AO, Faber PW, Van Rooij HC, Kuiper GG, Ris $C$. Klaassen $P$, et al. The human androgen receptor: domain structure, genomic organization and regulation of expression. J Steroid Biochem 1989;34:307-10.

23. Kuil $\mathrm{CW}$. Brinkmann $\mathrm{AO}$. Androgens, antiandrogens and androgen receptor abnormalities. Eur Urol 1996;29:78-82.

24. Brown CJ, Goss SJ, Lubahn DB, Joseph DR, Wilson E.M, French FS, et al. Androgen receptor locus on the human $X$ chromosome: regional localization to $\mathrm{Xq11-12}$ and description of a DNA polymorphism. Am J Hum Genet 1989;44:264-9.

25. Rundlett SE, Wu XP, Miesfeld RL Functional characterizations of the androgen receptor confirm that the molecular basis of androgen action is transcriptional regulation. Mol Endocrinol 1990;4:708-14.

26. Jenster $G$, Van Der Korput HA, Van Vroonhoven C, Van Der Kwast TH. Trapman J, Brinkmann AO. Domains of the human androgen receptor involved in steroid binding. transcriptional activation, and subcellular localization. Mol Endocrinol 1991:5:1396-404.

27. Simental JA, Sar M, Lane MV. French FS, Wilson EM. Transcriptional activation and nuclear targeting signals of the human androgen receptor. J Biol Chem $1991: 266: 510-18$.

28. Lubanh DB, Brown TR, Simental J, Higgs HN, Migeon CJ, 
Wilson EM, et al. Sequence of the intron/exon junctions of the coding region of the human androgen receptor gene and identification of a point mutation in a family with complete androgen insensitivity, Proc Natl Acad Sci U S A 1989:86:9534-8.

29. Ham J, Thomson A, Needham M. Webb P. Parker M. Characterization of response elements for androgens, glucocorticoids and progestiris in mouse marmmary tumor virus. Nucleic Acid Res 1988; 16:5263-76.

30. Sun Z, Pan J, Balk SP. Androgen receptor-associated protein complex binds upstream of the androgen responsive elements in the promoters of human prostate-specific antigen and kallikrein 2 genes. Nucleic Acid Res 1997;25:3378-25

31. Halachmi S, Marden E, Merti G. Mackay H, Abbondanza C. Brown M, et al. Estrogen receptor-associated pro teins: possible mediators of hormone-induced transcription. Science 1994:264:1455-8.

32. Hong $H$, Kohli $K$, Trived A, Johnson DL, Stallcup MR. GRIPI, a novel mouse protein that serves as a transcriptional coativator in yeast for the hormone binding domains of steroid receptors. Proc Natl Acad Sci USA 1996:93:4948-52

33. Oñate SA, Tsai SY, Tsai MJ, O'Malley BW. Sequence and characterization of a coactivator for the steroid hormone receptor superfamily. Science 1995;270:1354-57.

34. Yeh S, Chang $C$. Cloning and characterization of a spe cific coactivator, ARA 70 , for the androgen receptor in human prostate cells. Proc Natl Acad Sci USA 1996:93:5517-21

35. Chen JD. Evans RM. A transcriptional co-repressor that interacts with nuclear hormone receptors. Nature $1995: 377: 454-7$

36. Horlein AJ, Naar AM, Heinzel T, Torchia J, Gloss B Kurokawa R, et al. Nature 1995:377:397-403

37. Kurokawa R, Soderstrom M, Horlein AJ, Halachmi $S$ Brown M, Rosenfeld MG, et al. Polarity-specific activities of retinoic acid receptors determined by a co-repressor. Nature 1995;377:451-4

38. Kazemi-Esfarjani P. Trifiro MA, Pinsky L. Evidence for a repressive function of the long polyglutamine tract in the human androgen receptor: possible pathogenetic rele. vance for the (CAG)n-expanded neuronopathies. Hum Mol Genetic 1995:4:523-7.

39. Sleddens HFBM, Oostra BA, Brinkmann AO, Trapman J. Trinucleotide (GGN) repeat polymorphism in the human androgen receptor (AR) gene. Hum Mol Genel 1993:2:493.

40. Tut TG, Ghadessy FJ, Trifiro MA, Pinsky L, Yong EL. Long polyglutamine tracts in the androgen receptor are associated with reduced trans-activation, impaired sperm production, and male infertility. J Clinical Endocrinol Metabol 1997:82:3777-82

41. Irvine AR, Yu M, Ross RK, Coetzee GA. The CAG and GGC microssatellites of the androgen receptor gene are in linkage disequilibrium in men with prostate cancer. Cancer Res 1995;55:1937-40.

42. Giovannucci E, Stampfer MJ, Krithivas K, Brown M. Brufsky A. Talcott J, et al. The CAG repeat within the androgen receptor gene and its relationship to prostate can- cer. Proc Nafl Acad Sci USA 1997:94:3320-3

43. Gerber HP, Seipel K, Georgiev O, Hofferer M, Hug M, Rusconi $S$, et al. Transcriptional activation modulated by homopolymeric glutamine and proline stretches. Science 1994:263:808-11.

44. Wharton KA, Yedvobnick B, Finnerty. VG, Astavanis Tsakonas S. Opa: a novel family of transcribed repeats shared by the Notch locus and other developmentally regulated loci in D. melanogaster. Cell 1985:40:55-62

45. Hoffmann A, Sinn E, Vamamoto T. Wang J, Roy A Horikoshi M, et al. Highly conserved core domain and unique $\mathrm{N}$ terminus with presumptive regulatory motifs in a human TATA factor (TFII). Nature 1990:346:387-90.

46. Kao CC. Lieberman PM. Schrnidt MC, Zhou Q. Pei R, Berk A.J. Cloning of a transcriptionally active human TATA binding factor. Science 1990;29:1646-50

47. Rosemberg RN. DNA-triplet repeats and neurologic disease. N Engl J Med 1996:335:1222-4.

48. Davis DL, Russell DW. Unusual length polymorphism in human steroid 5a-reductase type 2 gene (SRD5A2). Hum Mol Genet 1993:2:820.

49. Reichardt JKV. Makridakis N. Henderson BE, Yu MC. Pike MC, Ross, RK. Genelic variability of the human SRD5A2 gene: implications for prostate cancer risk. Cancer Res 1995:55:3973-5.

50. Dawson NA. Hormonal therapy for prostate cancer: what you need to know. In: Proceedings of Annual Meeting of ASCO. Educational Book, 34, Los Angeles. Bologna:Monduzzi, 1998. p 368-72.

51. Kuil CW. Berrevoets CA, Mulder E. Ligand-induced conformational alterations of the androgen receptor analyzed by limited trypsinization. Studies on the mechanism of antiandrogen action. J Biol Chem 1995;270:27569-76.

52. Brinkmann AO, Lindh LMI, Bredveld DI, Mulder E, Van Der Molen HJ. Cyproterone acetate prevents translocations of the androgen receptor in the rat prostate. Mol Cell Endocrinol 1983;32:117-29

53. Segnitz B, Gehring U. Mechanism of action of a steroidal antiglucocorticoid in lymphoid cells, J Biol Chem $1990 ; 265: 2789-96$

54. Klein-Hitpass L, Cato ACB, Henderson D, Ryffel GU. Two types of antiprogestins identified by their differential action in transcriptionally active extracts from T47D cells. Nucleic Acid Res 1991:19:1227-34.

55. Isaacs JT, Coffey DS. Adaptation versus selection as the mechanism responsible for the relapse of prostatic cancer to androgen ablation therapy as studied in the Dunning R-3327-H adenocarcinoma. Cancer Res $1981: 41: 5070-5$.

56. Habibi FK. Steroid hormones and cancer: IV prostate cancer. Eur J Surg Oncol 1997:23:264-8

57. Hobisch A, Culing Z, Radmayr C, Bartsch G, Klocker H, Hittmair A. Distant metastases from prostatic carcinoma express androgen receptor protein. Cancer Res 1995:55:3068-72.

58. Gaddipati JP, Mcleod DG, Heindenberg HB, Sesterhenn A M. Finger MJ, Moul JW, et al. Frequent defection of codon 877 mutation in the androgen receptor gene in advanced prostate cancers. Cancer Res 1994:54:286 1-4. 
59. Paz A, Lindner A. Zisman A. Siegel Y. A genetic sequence change in the $3^{\prime}$-noncoding region of the androgen receptor gene in prostate carcinoma. Eur Urol 1997:31:209-15.

60. Harris SE, Rong Z, Harris MA, Lubahn DD. Androgen receptor in human prostate carcinoma LNCAP/ADEO cells contains a mutation which alters the specificity of the steroid-dependent transcriptional activation region. Endocrinology 1990:126:93.

61. Veldscholte J, Ris-Stalpers C. Kuiper $G G$, Jenster $G$. Berrevoets $C$. Claassen $E$, et al. A mutation in the ligand binding domain of the androgen receptor of human LNCaP cells affects steroid binding characteristics and response to anti-androgens. Biochem Biophys Res Commun 1990:173:534-40

62. Koivisto P, Kononen J, Palmberg C, Tammela T, Hyytinen E. Isola J, et al. Androgen receptor gene amplification: A possible molecular mechanism for androgen depriva tion therapy failure in prostate cancer. Cancer Res $1997 ; 57: 314-9$
63. Voeller HJ, Wildding $G$, Gelmann EP. V-H ras expression confers hormone independent growth to LNCaP prostate cancer cells. Mol Endocrinol 1991;5:209-16.

64. Rubin SJ, Hallahan DE, Ashman CR. Two prostate cancer cells lines demonstrate abnormalities in fumour supressor genes. J Surg Oncol 1991:46:31-6.

65. Bookstain R, Macgrogan D. Hilsenbeck SG, Sharkey F. Allred C. p53 is mutated in a subsel of advanced-stage prostate cancers. Cancer Res 1993:53:3369-73.

\section{Endereço para correspondência:}

Eloiza H. Tajara

Departamento de Biologia. IBILCE/UNESP

Caixa Postal 136

15054-000 São José do Rio Preto. SP

e.mail: tajara@bio.ibilce.unesp.br 